\title{
LEGAL ETHICS, A NEED FOR THE GOOD ADMINISTRATION OF JUSTICE
}

\section{D. Rath Boşca}

\section{Laura-Dumitrana Rath Boşca}

Law and Economics Faculty, Social Sciences Department, Agora University of Oradea, Oradea, Romania

*Correspondence: Laura-Dumitrana Rath Boşca, Agora University of Oradea, 8 Piaţa Tineretului St., Oradea, Romania

E-mail: dumitra1970@yahoo.com

\begin{abstract}
Ethics is the science of behavior and habits, a theoretical study of the principles that govern practical maters and moral represents all the means necessary for leaving.

Ethics consists of a number of rules that are shared by a certain community, rules that are essential for defining good and evil.

Being a branch of juridical science ethics analyses personal and professional conduit of the jurist it also manifests attention for the ethic of laws.
\end{abstract}

Keywords: Ethic, rationality, history, philosophy, ideas, opinions, concept of justice, responsibilities, jurists, lawyers, prosecutor, judges,

\section{Introduction}

Ethic is a normative, required science, ethic must be studied "not only for finding out what is virtue but mostly for becoming virtue." 1

Ethic, one of the most important branch of philosophy initiates itself in solving moral problems through a cognitive way, by knowing the good and the evil, by recognizing the duty each of us has to the society and to each of us.

We cannot speak about ethic without mentioning the three great philosophers, learners, views of Ancient Greece, that is Socrate, Platon and Aristotel. Even if the theories, these three great philosophers developed are in essence different, the common point we find even in the contemporary ethic theories is represented by the fact that happiness, virtue, good and rationality are included in the philosophic speech about ethic. The Greeks said that, the individual has to "follow the supreme good which is not limited to compliance with certain rules of behavior but it focuses on the constantly search upon the himself and by means of his capacities and the most important quality of the individual is the reason."

This way of explaining the world we leave in, of explaining and understanding the human being, that is by rational thought, affected the entire Western world, including the theology. As a consequence of this influence, the main objective of the scholars, as School of philosophy was the combination of reason, called also "the natural light" and theology. I mention here Toma d' Aquino who said that "reason becomes a pioneer for theology".

\footnotetext{
${ }^{1}$ Daniel Fodorean, Legal Ethics, Notes, 2010, Bucharest

${ }^{2}$ Toma d;Aquino, „About human being and essence”, Paideia Publishing house, 1995
} 
Sf. Anselm, called by the history of philosophy, the Father of scholars was the one who included the ontological argument of God, saying that: "I find evidence of negligence if, after we managed to have faith, we don't do our best to understand what we think."3

Ethic creates rules regarding both the behavior of the individual and the moral structure of the social life. Ethic analyses situations, cases and all the branches, such as: business ethics, biotic, medical ethics, international relationship ethics, media ethics, environment ethics and so one.

Descartes said that "the laws of nature are sufficient for explaining the harmonious composition of nature ${ }^{4}$. We may say, that our laws, the laws of people, that is both the moral and the legal ones, are not sufficient in clarifying whether we, the people are formed of harmony.

The complexity of our problems shows us that what we know represents almost nothing from what fallows to find. We can only try to find out, to know and to know each other.

We must decide ourselves to think, thought must proceed from a sense of life, from the humanist ethos of joy of life, of curiosity regarding the world and of thirst for certainty of thought and domination of nature, domination of our own spirituality, domination of our own morality.

It is interesting the contradiction between the opinions the people have and the their actions, between words and deeds.

The rationality is the one which determines us to support the "pass of thought" upon the process of knowing, upon the successive results of our own judgment.

We live in a society in which each of us may express his/her ideas, opinions, even if they are strange. We needed so much time for this. In the past, we must not forget that important people had suffered for expressing their opinions and thoughts. Some of them paid expensive price for what they were thinking, even with their own life. I give as example the tragic end of Giordano Bruno, who was burned on the stake by the Inquisition, it's pressure upon Galilei.

Let's remember about the Charron's book "About wisdom" where the French skeptic urged the readers " Not to fallow the known roads, but to walk on the blazed trails, never to judge according to the present opinions, but to avoid them, to create a new road, both in business and in science and religion."

One of our desire is "to live as happy as possible". Here comes another problem. Happiness means "something else" for each of us. Each of us has some values, has other opinions related to everything that surrounds us, to all we think and do.

In may opinion, nowadays we live a spiritual misalignment. Our values have no roots in the rationality, "the highest morality has no more the same meaning. The highest morality has to be a fruit of wisdom, of science and must not be limited only to rationality, which is also different from person to person. The rationalist ethos starts from Rationality, relies always on it, but includes also some other values which are not intellectual, but affective and social.

What is important for our study are the concept of justice, just and unjust in comparison to people's behavior in society, at work and within his/her own family.

Man cannot but inside human society and every society needs a structure, order and discipline, and the actions of people generally have to meet a moral needs of the society to express its values ${ }^{5}$.

\footnotetext{
${ }^{3}$ http://tonysss.wordpress.com/2007/01/19/sfantul-anselm-si-argumentul-ontologic/

${ }^{4}$ Rene Descartes, ,Speech about the methode of good thinking and finding the truth in science”, Academiei Române Publishinghouse, Bucharest 1990

${ }^{5}$ Laura-Roxana Popoviciu, Drept penal. Partea generală, Pro Universitaria Publishimg House, Bucharest, 2011, p.12.
} 
All that is unfair, illegal or not allowed are opposite to the term of just. Justice has to be seen also as a moral virtue. The name of justice comes from the Latin JUSTITIA, which derives from Justus, which also derives from jus, juris which means right. The original notion of jus is religious, meaning involving in a sacred formula, meaning to swear. In ancient times, the oath was sacred, represented the commitment of incurring penalty in case of breaking or not respecting it.

He legal ethic is a branch of legal sciences which studies the individual and professional behavior of the lawyer. Only by having the legal ethic he/she may acquire the respect and the trust of society. Also, the legal ethic demonstrates interest for the ethic of legal rules.

These aspects studies by the legal ethic gives several advantages, such as: the individual and professional authenticity, avoids the raise of corruption in society, creates legal rules well created from the moral point of view, promote the ethic in society.

The code of Ethics of the jurists, lawyers, prosecutor, judges, etc establish levels of behavior in compliance with honor and dignity of the profession.

The social reality, the official documents issued by the national and international institutions about Romania demonstrate that the study of ethics has become a present-day necessity.

The reports of European Union about the Romanian legal system emphasizes not only systemic errors but also the fact that the personal and professional ethics is focused more on the economical values than on the moral-ethical ones. " a better analyze gives the conclusion that the legal system is the projection of a society in a great need of a moral reform"

There are institutions and organizations that made great efforts to define a desirable behavior of those who work in the legal system and the standards are included in some instruments, such as The Code of Conduct of those who apply the law (ONU 1979), this code applies to people with political duties, especially that of arrest and detention, that is policemen, prosecutors, judges, officials from the Prisons from our country. The articles of this code say that the responsibilities are exercised for the community, for the protection of people against the illegal actions, the agents being forced to respect the human rights and to use force only when it is absolutely necessary, to keep the privacy policy of the obtained information, not to provoke, not to tolerate torture or cruelty, to assure the health of the arrested people and to prevent the violation of these.

The application of the code is encouraged by the " The guide for effective implementation of the Code of Conduct of those who apply the law" ECOSOC 1989, where it is recommended to give maximum importance to selection, education and forming of the officials.

It is important to speak also about the International Code of Conduct of the public agents, UN 1996. By this code, UN declare the corruption as being a problem which affects the stability and the security of citizens, damages the democracy and morality, o problem which prevents the economical, social and political development. This code is recommended as an instrument for all the countries to fight against the corruption. It includes the general principles for the conduct of the public agents, the principles of prevention of the conflicts of interest, wealthy statements, codes acceptance, management of the confidential information and involvement in political activities.

Also, the Bangalore Principles (India) 2001 regarding the legal conduct, where the UN showed that a serious obstacle in implementation of any anti-corruption strategy is the corruption from justice, the extension of it in the courts of many countries all over the world, being carefully examined by specialists who made the program to strengthen judicial integrity. Actually, it is about a code of conduct for the judges, but in Romania it is applied

\footnotetext{
${ }^{6}$ Transparency International Report
} 
also to the prosecutors. When the code was developed there were taken into consideration the main international documents in this field made by institutions and organizations from various countries. The code speaks about values as: Independence, Impartiality, Integrity, Label, Equality, Competence and Endeavor.

It is necessary to remember also about the Advisory Board of the European Prosecutors, an advisory body of the Board of Ministers of the European Council, established in 2005 for to institutionalizing the meetings that were taken part so far as conferences of the General Prosecutors from Europe. At this kind of meeting, which took place in Budapest was adopted in May 31, 2005 an European Guide upon the ethics and the conduct of the prosecutors.

The two advisory councils, that of the judges and the one of the prosecutors highlighted that "For a good administration of justice it is necessary to share the legal principles and the ethic values by all those who work in this field and are involved in a legal trial."

Also, the General Assembly of the European network of the Legal Council, within the London Meeting, 2-4 June 2010 appreciates that: "RECJ has as an objective the improvement of the cooperation and a good understanding between the Legal Councils and the members of the legal forces from Member States and the acceding States to European Union and the assertion of principles and common values at he European level in order to concrete the mutual understanding and therefore the mutual understanding between judges within the European legal space", .

Among the introduction of the Report regarding the legal ethics 2009-2010 it is mentioned that the conduct principles were written according to the decision which was approved at the General Meeting of the European Network of the Legal Councils (RCEJ) organized in June 2007 at Brussels

"The assertion of the professional ethics principles for judges strengthen the public trust and allows a better understanding of the role the judge has in society. Traditionally, the role of the judge is that of solving the conflicts by using the law. He has the duty to act according to the law and it is a guarantee of the fact that the judge won't have an arbitrary attitude. But, in the European society, the role of the judge evolved: he is no more limited on being "the voice of law" but he is also, in a certain case, the creator of law, which implies responsibilities and rules of conduct consistent with this evolution.",

It is important that any professional who works in the legal system to be concerned about the development of a balance between the independence of justice, the transparence of the institutions, the freedom of press and the right to information for the public. The professionals from the legal system must understand that the society has great expectations and that the protection of independence of justice is real important, it shouldn't be affected by pressure and manipulations.

\section{Bibliography}

Daniel Fodorean, Legal ethics, Notes, 2010, Bucharest

The statement regarding the legal ethics, London, 2010;

RECJ Group of work, Legal ethics, Report 2009 2010, Legal ethics, Principles, Values and qualities

Transparency International Report

Copoeru Ion, Szabo Nicoleta, Ethic and professional culture, Casa Cărții de Ştiință Publishing house, Cluj-Napoca, 2008;

Laura-Roxana Popoviciu, Drept penal. Partea generală, Pro Universitaria Publishimg House, Bucharest, 2001, p.12

\footnotetext{
${ }^{7}$ The statement regarding the legal ethics, Londra 2010

${ }^{8}$ RECJ Group work, Legal ethic, Report 2009 - 2010, Legal Ethic, Pinciples, Values and qualities
} 
Bauman,Z. Postmodern ethic, Timişoara, Amarcord Publishing house, 2000; Bihan Le Christie, The great problems of ethic, Iaşi, European Institute, 1999; Mara, A. Moral relativism and its values, Cluj-Napoca, EFES Publishinghouse, 1998; Toma d, Aquino, About human being and essence, Paideia Publishinghouse, 1995;

Rene Descartes, The speech about the methode of good thinking and searching for the truth in science, Academiei Române Publishinghouse, 1990;

The international covenant regarding the civil and political rights from December 16, 1966, New York;

The code of ethics of the International Association of the Lawyers, from 1956

European Human Rights Agreement, Stasbourg, September 13,1953;

Universal Declaration of Human Rights, adopted at the General Meeting of ONU on December 10, 1948

http://tonysss.wordpress.com/2007/01/19/sfantul-anselm-si-argumentul-ontologic/ 